\title{
Tectonic Setting of the Cu-Ni Sulfide-Bearing Mafic-Ultramafic Complexes in Northern Jilin Province, NE China
}

\author{
Dacheng $\mathrm{Jia}^{{ }^{*}}$, Shen $\mathrm{Liu}^{2}$, Hong Zhong ${ }^{2}$, Guangying Feng ${ }^{2}$, Youqiang $\mathbf{Q i}^{2}$, \\ Wen Gao ${ }^{1}$, Xiao Zhang ${ }^{1}$, Tao Jiang ${ }^{1}$, Yongxin Mao ${ }^{1}$ \\ ${ }^{1}$ College of Geo-Exploration and Science and Technology, Jilin University, Changchun, China \\ ${ }^{2}$ State Key Laboratory of Ore Deposit Geochemistry, Institute of Geochemistry, \\ Chinese Academy of Sciences, Guiyang, China \\ Email: jiadacheng@sina.com
}

Received November 12, 2012; revised January 7, 2013; accepted February 4, 2013

\begin{abstract}
There are series of $\mathrm{Cu}-\mathrm{Ni}$ sulfide-bearing mafic-ultramafic intrusions widespread in north Jilin Province, Northeastern China. The intrusions formed in Xing'an-Mongolian Orogenic Belt near to the northeastern margin of North China Craton. The complexes were formed in almost same period according to the zircon $\mathrm{U}-\mathrm{Pb}$ dating reported recently, which means that the complexes were formed in same tectonic period and belong to one tectonic magmatic event. The rock assemblages are different from the ophiolite type and Yidun type in orogenic belt. The mafic-ultramafic complexes formed in the range from $217 \mathrm{Ma}$ to $232 \mathrm{Ma}$ coeval with A-type granites in the area, which formed bimodal igneous rock assemblage. According to the regional angular unconformities, there were existed the orogenies of Caledonian, Hercynian, Early Indosinian, Late Indosinian and Yanshanian. The Early Indosinian coeval with orogenic I-type granites and sanukitie that suggesting the lithosphere thickening in the extrusion tectonic setting of orogenic processes, however the Late Indosinian coeval with bimodal igneous rock assemblage that suggesting the lithosphere thinning in the extension tectonic setting of post-orogenic processes in the Xing'an-Mongolian Orogenic Belt. Chemical composition of the mafic-ultramafic rocks has the characteristics of high-Mg and low-K tholeiites related with inter-continental post-orogenic tectonic setting. The trace elements indicate their formed in conditions of continental extension belt or initial rift and has the characteristics of revolution from oceanic island arc, volcanic arc of continental margin to continental extended belt. The low initial $\mathrm{Sr}$ isotopic ratios and positive $\varepsilon_{\mathrm{Nd}}(\mathrm{t})$ values suggest that the initial magma of the complexes come from the parting melting of depleted lithospheric mantle. The depleted ithospheric mantle was new formed supported by zircon $\mathrm{Hf}$ isotope in Hongqiling complex. The depleted lithospheric mantle may be caused by the asthenosheric mantle upwelling and underplating in the tectonic setting of extension during the Late Indosinian post-orogenic processes.
\end{abstract}

Keywords: Mafic-Ultramafic Intrusions; Tectonic Setting; Post-Orogenic Processes; Lithospheric Extension

\section{Introduction}

The mafic-ultramafic magmatism is the major geological procession in mantle and was controlled by various factors, but tectonic setting is more important factor for restricting the activity and the nature of the magma. The special rock assemblage formed in particular tectonic setting [1,2]. There are more than hundreds maficultramafic intrusions widespread in Northern Jilin Province Northeastern China by the field geological investigation [3]. Although there are number of study on petrology, mineralogy, ore deposit and geochemistry, most of them is on Hongqiling $\mathrm{Cu}-\mathrm{Ni}$ sulfide-bearing mafic-ultramafic

*Corresponding author.
Intrusions [4-6], but relater to the tectonic setting of the mafic-ultramafic intrusions were seldom researched and raises question about the tectonic setting, especially on the mafic-ultramafic magmatic event, which constraints the conditions of mineralization and understanding of the regional tectonic revolution.

There are tow major different tectonic settings in Jilin Province divided by Huifahe-Gudonghe deep fault, the southern part is be long to North China Craton and the northern part is be long to Xing'an-Mongolian Orogenic Belt [7]. The $\mathrm{Cu}-\mathrm{Ni}$ sulfide-bearing mafic-ultramafic complexes developed both in the tow part. The maficultramafic complexes in Craton was formed in the continental rift as general understanding $[1,8]$, but the tectonic 
setting of mafic-ultramafic complexes in orogenic belt have various comprehends [9-13]. As the dating for the mafic-ultramafic intrusion is based of K-Ar method in previous research, most of the intrusions were regarded as Hercynian period, so the tectonic setting was regarded as Hercynian fold bel $t$ [11], margin or accretion fold belt of paleo-plate [4], back arc of North China Plate [10]. As the zircon $\mathrm{U}-\mathrm{Pb}$ dating method for mafic-ultramafic intrusion was used frequently and the advance on research of Xing'an-Mongolian Orogenic Belt, the intrusions were regarded as Early Triassic period from extrusion to extension system related to the colliding orogeny between the North China Plate and Siberia Plate [13], and regarded as Late Triassic period from extension system related to the post-orogeny $[12,14]$. However, most of the research is focused on the Hongqiling complex, whether the other complexes were the same tectonic setting needs to be discussed. In this paper, we summarized the rock assemblages of mafic-ultramafic intrusions in Northern Jilin Province, discussed the ages of the complexes and mag- matic events. The tectonic setting of the complexes is discussed in terms of extension in post-orogenic processes and magmatic sources of the complexes are discussed associated with the lithochemistry.

\section{Geological Setting and Rock Assemblage}

There are some typical mafic-ultramafic complexes in Northern Jilin Province, such as Shanmen complexes, Chajialing complexes, Sandaogang complexes, Hongqiling complexes, Piaohechuan complexes, Changren complexes, Zhangxiang complexes, widespread in fold orogenic belt along the northern margin of North China Craton (Figure 1), some of them contain economic resources of $\mathrm{Cu}$ and $\mathrm{Ni}$, among of them Hongqiling complexes contain second larger $\mathrm{Cu}-\mathrm{Ni}$ sulfide deposit in
China. The complexes were controlled by faults and consist of some intrusions. Single intrusion is small in size and intruded in dikes. The intrusions show obviously intrusive relations with the host rocks and the oldest strata they intruded is Early-Paleozoric Hulan Group and the youngest strata is Late Permian Fanjiatun Group. The intrusions intruded into Early Indosinian Dayushan granite [15], which indicate the mafic-ultramafic complexes were magmatic event in Late Indosinian.

Based on the summarized of the mafic-ultramafic rocks, it can be divided in some rock assemblages: 1) orthopyroxene-websterite type, represented by the No. 7 and No. 32 intrusion in Hongqiling complex, Cu-Ni mineralization was in the orthopyroxene; 2)peridotitepyroxenolite type, represented by the No. 1 intrusion in Hongqiling complex, $\mathrm{Cu}-\mathrm{Ni}$ mineralization was in the peridotite; 3)hornblendite type, represented by the No. 6 intrusion in Hongqiling complex; 4) pyroxenolite-peridotite-gabbro type, represented by the No. 2 intrusion in Hongqiling complex, $\mathrm{Cu}-\mathrm{Ni}$ mineralization was in the peridotite; 5) amphibole gabbro-olivine pyroxenolite type, represented by the No.4 intrusion in Piaohechuan complex, $\mathrm{Cu}-\mathrm{Ni}$ mineralization was in the olivine pyroxenolite; 6) gabbro-amphibolite-pyroxenolite-harzburgite type, represented by the No. 8 intrusion in Shanmen complex, $\mathrm{Cu}-\mathrm{Ni}$ mineralization was in the harzburgite; 7) amphibolite-orthopyroxenite type, represented by the No. 3 intrusion in Hongqiling complex. According to the genesis classification of ultramafic and mafic rocks [1], those complexes belong to the type of active orogenic belt, difference from the type emplaced in Craton or plateform. There are may be ophiolite-types, Yidun-types and Alaska-type mafic-ultramafic rocks roughly in orogenic belt [8], but the complexes have not show the features of ophiolite in rock assemblages and suture belt, on the

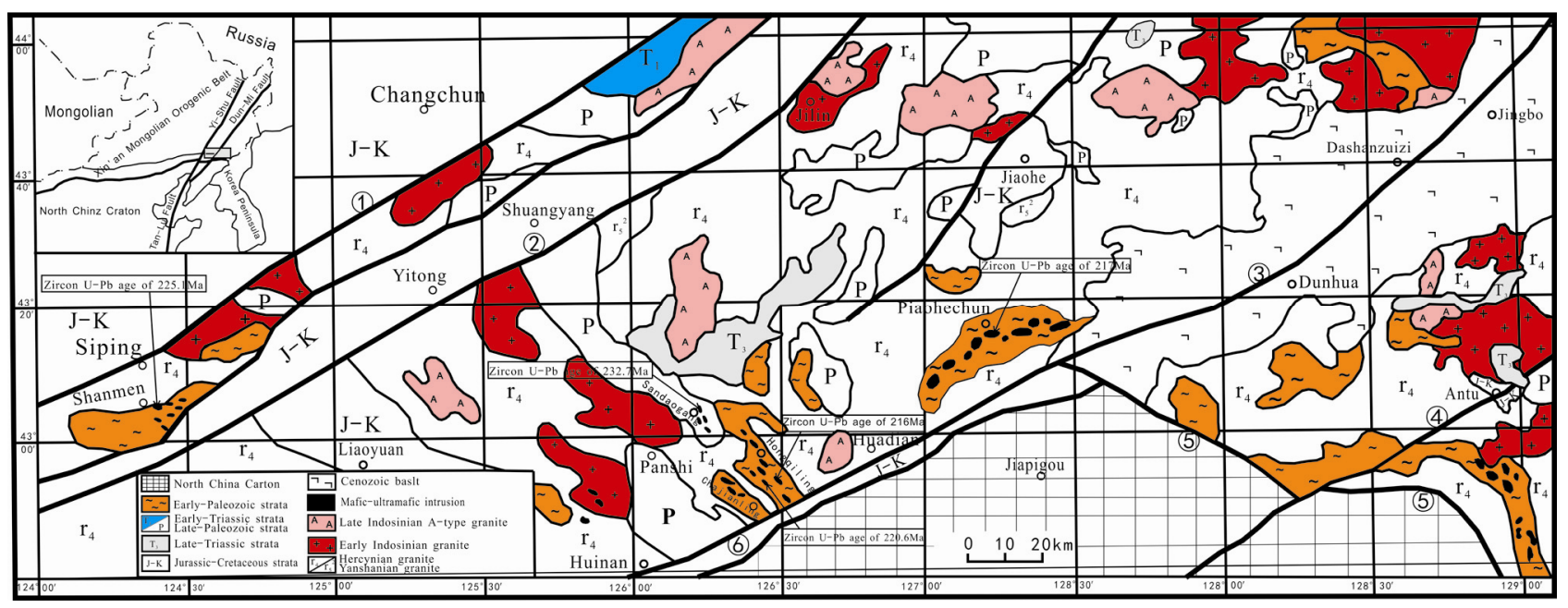

Figure 1. Distribution of mafic-ultramafic complexes in North Jilin Province, NE China. (1) Fault of Songliao basin margin; (2) Yi-Shu Fault; (3) Dun-Mi Fault; (4) Liangjiang Fault; (5) Gudonghe Fault; (6) Huifahe Fault. 
other hand, the rock lack metamorphism, seldom gabbro-diabase-diorite assemblages and cumulus crystal structure, so the rock should not belong to Yidun-types and Alaska-type intrusion in active orogenic belt. This suggests that the rock assemblage may be particular types in orogenic belt and formed in special tectonic setting. As orogenic movement can be divided the orogenic period and post-orogenic period $[16,17]$, so the rock assemblage indicates it may be related with the magmatism of post-orogenic period.

\section{Age of the Complexes and the Bimodal Igneous Rock Assemblage}

As the application of zircon U-Pb dating for maficultramafic rocks, most of the complexes have precise ages. The zircon U-Pb age of gabbro in Shanmen complexes is 225.1 Ma (MSWD = 2.7) [18]; The zircon $\mathrm{U}-\mathrm{Pb}$ age of gabbro in Sandaogang complexes is $232.75 \pm 0.95 \mathrm{Ma}$ $(\mathrm{MSWD}=0.87$ ) [19]; The zircon $\mathrm{U}-\mathrm{Pb}$ age of leucogabbro in Hongqiling No. 1 intrusion is $216 \pm 5.0 \mathrm{Ma}$ [12]; The zircon U-Pb age of olivine websterite in Hongqiling No. 2 intrusion is $220.6 \pm 2.0 \mathrm{Ma}$ [14]; The zircon $\mathrm{U}-\mathrm{Pb}$ age of Pl-bearing pyroxenite in Piaohechun No. 4 intrusion is $217 \pm 3.0 \mathrm{Ma}$ [12]. The zircon $\mathrm{U}-\mathrm{Pb}$ age of the rocks are range from $217 \mathrm{Ma}$ to $232.75 \mathrm{Ma}$ based on reported recently, which expressed that those complexes were formed in narrow time stage, therefore it can be interpreted as one magmatic event in the orogenic revolution. The magmatic event was accordance with the Late Indosinian tectonic movement.

There were some A type granites occurred in north Jilin Province with the age is from 230 to $190 \mathrm{Ma}$ dated by zircon $\mathrm{U}-\mathrm{Pb}[20]$, which indicated that the maficultramafic complexes formed in the period of 217 - $233 \mathrm{Ma}$ are coeval with the A type granites in the same area, therefore the mafic and acidic rocks formed the typical bimodal igneous rock assemblage. Whereas the mafic rocks formed in shorter period and the A type granites formed in longer period relatively. The bimodal igneous rock assemblage indicates that the complexes developed in the tectonic setting of continental extension and belong to Late Indosinian post-orogenic processes of Xing'an-Mongolian Orogenic Belt.

\section{Geochemical Characteristics of the Maficultramafic Complexes}

\subsection{Feature of Major Elements}

The mafic-ultramafic rocks are low in silica, with $\mathrm{SiO}_{2}$ ranging from $39.85 \%$ to $48.99 \%$ and the $\mathrm{SiO}_{2}$ contents of pyroxenite are higher than peridotite. The rocks are low in $\mathrm{K}_{2} \mathrm{O}$ and $\mathrm{Na}_{2} \mathrm{O}$, with $\mathrm{K}_{2} \mathrm{O}$ ranging from $0.10 \%$ to $0.17 \%$ and $\mathrm{Na}_{2} \mathrm{O}$ ranging from $0.15 \%$ to $2.13 \%, \mathrm{Na}_{2} \mathrm{O}>$ $\mathrm{K}_{2} \mathrm{O}$. The rocks have high $\mathrm{MgO}$ contents, $\mathrm{MgO}$ ranging from $32.10 \%$ to $13.21 \%$ and $\mathrm{Mg}^{\#}\left(\mathrm{Mg}^{\#}=100 \times \mathrm{MgO} /\right.$ $(\mathrm{MgO}+\mathrm{FeO})$ ranging from 80 to 56 (Table 1), which implicit that the rocks come from the low degree differentiated magma [21] and be long to high-Mg and low $\mathrm{K}$ tholeiitic series. The $\mathrm{Mg}^{\#}$ values trend reducing along with the $\mathrm{Si}_{2} \mathrm{O}$ increasing, which indicate the rocks formed by fractional crystallization. The most rocks put in the $\mathrm{CAB}$ regain and some rocks put in the IAT regain in the $\mathrm{TiO}_{2}-\mathrm{MnO}-\mathrm{P}_{2} \mathrm{O}_{5}$ diagram (Figure 2), which reflect the rocks may be formed in continental orogenic belt.

Table 1. Major elements composition of the mafic-ultramafic rocks in North Jilin Province, China.

\begin{tabular}{|c|c|c|c|c|c|c|c|c|c|c|c|c|}
\hline Sample No. & YS-4 & YS-1 & S-16 & HQL1 & HQI1-2 & HQLF & $\mathrm{H} 7$ & HQV7 & P4-8 & $\mathrm{C} 1-6$ & C7-15 & Z1-5 \\
\hline Location & \multicolumn{3}{|c|}{ Sandaogang } & \multicolumn{3}{|c|}{ Hongqiling No. 1 intrusions } & \multicolumn{2}{|c|}{ Hongqiling No. 7 intrusions } & Piaohe-chuan & \multicolumn{2}{|c|}{ Changren } & Zhang-xiang \\
\hline Sample Numb & 1 & 1 & 2 & 1 & 7 & 20 & 3 & 4 & 4 & 6 & 9 & 5 \\
\hline $\mathrm{TiO}_{2}$ & 0.48 & 0.61 & 0.28 & 0.39 & 6.14 & 0.23 & 0.72 & 5.30 & 1.16 & 0.48 & 0.43 & 0.35 \\
\hline $\mathrm{Al}_{2} \mathrm{O}_{3}$ & 4.42 & 4.78 & 3.01 & 5.35 & 0.36 & 3.67 & 4.47 & 0.41 & 9.83 & 6.94 & 5.89 & 5.98 \\
\hline $\mathrm{Fe}_{2} \mathrm{O}_{3}$ & 3.66 & 9.03 & 13.43 & & $10.90^{*}$ & 11.52 & & $13.49^{*}$ & & 2.19 & 3.50 & 2.42 \\
\hline $\mathrm{FeO}$ & 10.80 & 8.18 & 10.42 & 9.61 & & & 12.41 & & 12.89 & 7.02 & 7.38 & 7.48 \\
\hline $\mathrm{MnO}$ & 0.32 & 0.20 & 0.10 & 0.15 & 0.16 & 0.14 & 0.15 & 0.13 & 0.19 & 0.16 & 0.13 & 0.13 \\
\hline $\mathrm{MgO}$ & 28.23 & 13.21 & 13.34 & 32.10 & 30.60 & 30.28 & 29.25 & 24.86 & 17.43 & 23.57 & 29.52 & 28.18 \\
\hline $\mathrm{CaO}$ & 2.81 & 13.64 & 8.08 & 5.66 & 4.08 & 4.68 & 2.34 & 2.36 & 7.39 & 5.70 & 3.33 & 5.21 \\
\hline $\mathrm{Na}_{2} \mathrm{O}$ & 1.10 & 0.86 & 0.12 & 6.41 & 0.81 & 0.16 & 0.58 & 0.79 & 1.67 & 0.83 & 0.74 & 1.83 \\
\hline $\mathrm{K}_{2} \mathrm{O}$ & 0.80 & 0.35 & 0.08 & 1.23 & 0.29 & 0.11 & 0.39 & 0.41 & 1.01 & 0.50 & 0.45 & 0.35 \\
\hline Los & 4.79 & 6.85 & 10.27 & 5.43 & 6.19 & 5.87 & 3.15 & 10.61 & 2.20 & 4.34 & 4.98 & 4.78 \\
\hline Total & 97.58 & 99.30 & 100.6 & 98.53 & 99.88 & 100.2 & 99.55 & 98.83 & 99.60 & 100.3 & 99.08 & 100.1 \\
\hline $\mathrm{Mg}^{\#}$ & 72 & 62 & 56 & 77 & 70 & 57 & 71 & 74 & 72 & 77 & 80 & 79 \\
\hline
\end{tabular}

"means as TFeO; $\mathrm{Mg}^{\#}=100 \times \mathrm{MgO} /(\mathrm{MgO}+\mathrm{FeO})$; Samples of HQL1, H7 and P4-8 are average values after [14]; HQI1-2 and HQV7 are average values after [13]; Samples of HQLF are average values after [14]. 


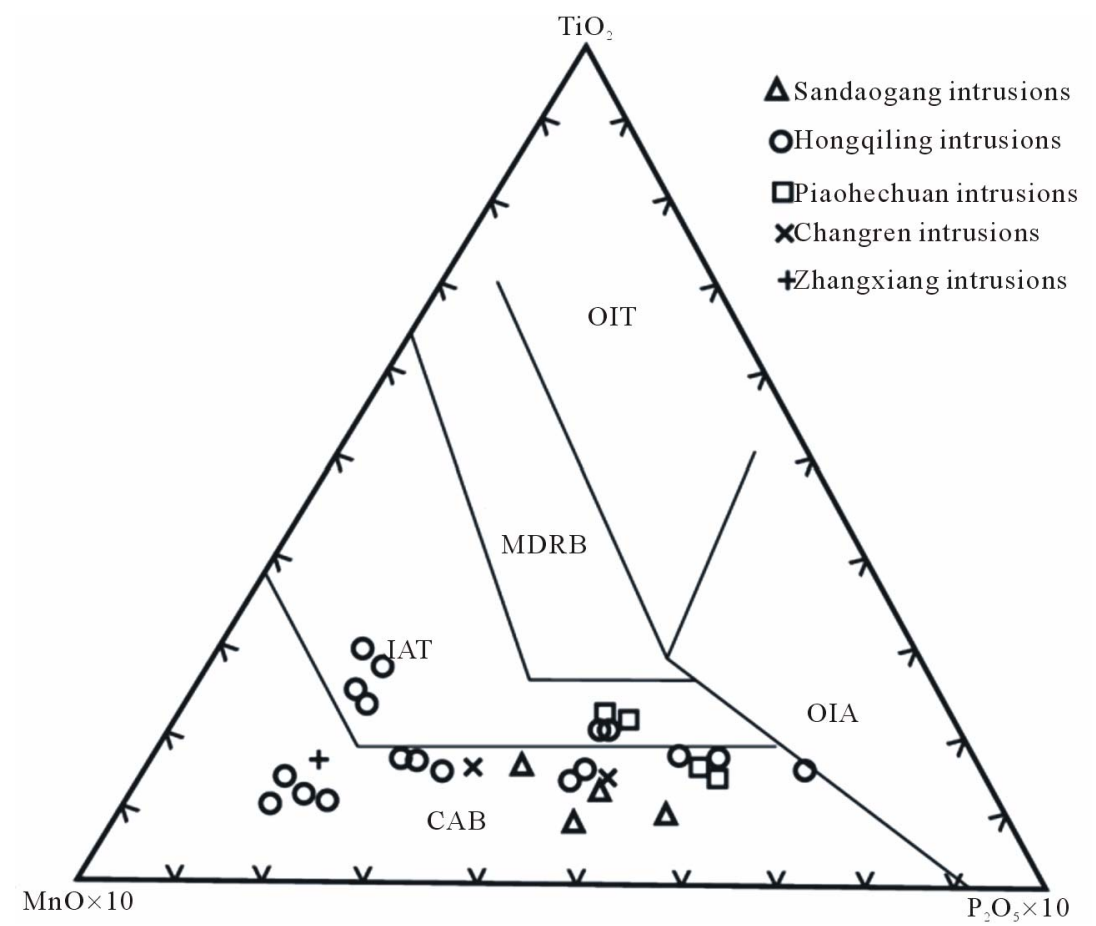

Figure 2. $\mathrm{TiO}_{2}-\mathrm{MnO}-\mathrm{P}_{2} \mathrm{O}_{5}$ discrimination diagram for mafic-ultramafic intrusions; CAB, continental basalt; MORB, midoceanic ridge basalt; IAT, island arc and volcanic arc tholeiite basalt; OIT, oceanic island tholeiite basalt; OIA, oceanic alkaline island.

\subsection{Feature of Trace Elements}

In the Chondrite-normalized REE diagrams, the samples show LREE enrichment $\left((\mathrm{La} / \mathrm{Yb})_{\mathrm{N}}=1.95-2.61\right)$ and no or slightly negative $\mathrm{Eu}$ anomalies $(\delta \mathrm{Eu}=0.77-1.11)$. The range of REE is from 155.3 to 23.11 (Table 2), which appears large variations of the REE patterns (Figure 3). In the primitive mantle-normalized variation diagrams, all of the samples show characteristics of the negative anomalies in $\mathrm{Nb}$, Ta and $\mathrm{Zr}$ (Figure 4), which indicates addition of crustal components to the magma.

As almost all rocks put in the field of intra continental basalt(WPB) or continental arc in the $\mathrm{Zr} / \mathrm{Y}-\mathrm{Zr}$ diagram (Figure 5(a)), similar with the major elements (Figure 2), so the rocks put in the fields of $\mathrm{C}$ and $\mathrm{D}$ reflect that the rocks were not formed in volcanic arc related with the subduction or oceanic island, but formed in intra continental active belt related with the deficit MORB in $\mathrm{Nb}-\mathrm{Zr}$ - $\mathrm{Y}$ diagram(Figure 5(b)). In the normal continental orogenic belt, the depleted mantle and deficit MORB were formed in the post-orogenic period associated with the crustal extension [22,23].

$\mathrm{In} \mathrm{Th/Hf-Ta/Hf} \mathrm{diagram,} \mathrm{small} \mathrm{of} \mathrm{the} \mathrm{rocks} \mathrm{are} \mathrm{put} \mathrm{in}$ the fields of island arc and volcanic arc of continental margin, but most of the rocks are put in the fields of continental extensional belt, which indicated the tectonic setting of within continent (Figure 6).

Based on the rate of $\mathrm{Th} / \mathrm{Nb}$, the tectonic setting of ocean and continent can be divided by $\mathrm{Th} / \mathrm{Nb}=0.11$, which is similar the value of initial mantle $[25,26]$, the basaltic rocks formed within continent with $\mathrm{Th} / \mathrm{Nb}>0.11$ and formed within ocean such as MORB and OIB with $\mathrm{Th} / \mathrm{Nb}<0.11$, the $\mathrm{Th} / \mathrm{Nb}$ of all rocks are $>0.11$ (Figure 7). $\mathrm{In} \mathrm{Th} / \mathrm{Zr}-\mathrm{Nb} / \mathrm{Zr}$ diagram, small of the rocks are put in the fields of island arc and volcanic arc of continental margin, some of the rocks are put in the fields of collision zone and large of the rocks are put in the fields of continental extensional zone (Figure 7). According to the model of continental crust accretion [27], the revolution of continental crust is from oceanic island $\operatorname{arc}\left(\mathrm{II}_{1}\right)$ to island arc or volcanic arc of continental margin $\left(\mathrm{II}_{2}\right)$, continental collision zone $\left(\mathrm{IV}_{3}\right)$, and to continental extensional zone $\left(\mathrm{IV}_{2}\right)$, along with the direction of arrow (Figure 7). From the oceanic island $\operatorname{arc}\left(\mathrm{II}_{1}\right)$ to island arc or volcanic arc of continental margin $\left(\mathrm{II}_{2}\right)$ implies the extrusion tectonic setting related with the subduction of oceanic plate, the rate of $\mathrm{Nb} / \mathrm{Zr}$ is $<0.04$ in this stage. From the continental collision zone $\left(\mathrm{IV}_{3}\right)$ to the continental extensional zone $\left(\mathrm{IV}_{2}\right)$ implies the transformation from the extrusion orogenic belt to the extensional post-orgenic belt, the rate of $\mathrm{Nb} / \mathrm{Zr}$ is $>0.04$ in this stage (Figure 7). Therefore the rocks finally formed in the post-orogenic belt (Figure 7).

\subsection{Feature of Isotopes}

The Sr-Nd isotopic data in Hongqiling show low initial ${ }^{87} \mathrm{Sr} /{ }^{86} \mathrm{Sr}$ rations, the ranger is between 0.70394 to 
Table 2. Trace elements composition of the mafic-ultramafic rocks in North Jilin Province, north China.

\begin{tabular}{|c|c|c|c|c|c|c|c|c|c|c|c|c|}
\hline Sample No. & YS-20 & YS-6 & S-16 & S-19 & HQL2-3 & HQL02-5-7 & HQI-11-20 & HQLF-11 & $\mathrm{H} 7-3-5$ & HQV-5-21 & HQV-7-20 & P4-8 \\
\hline Location & \multicolumn{4}{|c|}{ Sandaogang } & \multicolumn{4}{|c|}{ Hongqiling No. 1 intrusions } & \multicolumn{3}{|c|}{ Hongqiling No. 7 intrusions } & Piaohe-chuan \\
\hline Sample No. & 1 & 1 & 1 & 1 & 1 & 2 & 3 & 20 & 3 & 2 & 2 & 4 \\
\hline $\mathrm{V}$ & 47.70 & 75.50 & 34.90 & 78.00 & 46 & 63.50 & 88.13 & 78.2 & 37.63 & 72.55 & 77.30 & 135 \\
\hline $\mathrm{Cr}$ & 272.2 & 1423 & 1423 & 1543 & 2466 & 1029 & 4484 & 2700 & 1197 & 2618 & 2774 & 1018 \\
\hline $\mathrm{Co}$ & 940 & 211 & 790 & 330 & 109 & 72.50 & 200 & 122 & 91.03 & 138 & 366 & 84.30 \\
\hline $\mathrm{Ni}$ & 96100 & 7780 & 27600 & 18200 & 1124 & 1140 & 6350 & 1180 & 2523 & 3155 & 13830 & 921 \\
\hline $\mathrm{Rb}$ & 1.00 & 3.70 & 1.00 & 1.00 & 7.90 & 24.95 & 8.000 & 3.36 & 12.67 & 16.00 & 17.40 & 28.28 \\
\hline $\mathrm{Sr}$ & 41.8 & 61.1 & 44.1 & 36.2 & 140 & 449 & 120 & 70.4 & 215 & 151 & 358 & 453 \\
\hline $\mathrm{Zr}$ & 33.58 & 46.04 & 49.20 & 56.46 & 29.1 & 128 & 52.51 & 16.40 & 52.07 & 60.44 & 82.63 & 102 \\
\hline $\mathrm{Hf}$ & 2.10 & 2.50 & 2.40 & 2.30 & 0.81 & 3.34 & 2.02 & 0.50 & 1.55 & 2.08 & 1.43 & 2.74 \\
\hline $\mathrm{Nb}$ & 1.50 & 2.70 & 1.80 & 2.90 & 0.69 & 5.17 & 2.50 & 0.40 & 2.20 & 2.85 & 3.40 & 4.89 \\
\hline $\mathrm{Ta}$ & 0.40 & 0.40 & 0.40 & 0.40 & 0.06 & 0.48 & 0.16 & 0.03 & 0.22 & 0.18 & 0.25 & 0.35 \\
\hline $\mathrm{Ba}$ & 88.50 & 37.90 & 51.30 & 41.80 & 83 & 375 & 71.33 & 28.50 & 117 & 121 & 204 & 316 \\
\hline $\mathrm{Pb}$ & 61.70 & 14.80 & 20.00 & 19.60 & 2.30 & 9.50 & 13.18 & 1.87 & 7.97 & 11.75 & 30.30 & 42.65 \\
\hline Th & 4.15 & 2.35 & 5.56 & 3.98 & 0.56 & 4.18 & 1.60 & 0.35 & 3.19 & 2.15 & 1.88 & 3.85 \\
\hline $\mathrm{U}$ & 1.23 & 0.98 & 1.54 & 1.43 & 0.14 & 2.70 & 1.42 & 0.06 & 1.48 & 1.76 & 2.77 & 0.91 \\
\hline $\mathrm{La}$ & 24.49 & 5.08 & 5.08 & 4.91 & 3.36 & 24.77 & 3.92 & 1.86 & 10.86 & 5.25 & 9.57 & 22.10 \\
\hline $\mathrm{Ce}$ & 50.82 & 12.12 & 12.12 & 12.38 & 7.20 & 54.85 & 9.52 & 4.24 & 28.37 & 14.22 & 21.35 & 65.40 \\
\hline $\operatorname{Pr}$ & 6.13 & 1.53 & 1.53 & 1.81 & 1.08 & 7.78 & 1.28 & 0.64 & 3.40 & 1.96 & 2.64 & 7.80 \\
\hline $\mathrm{Nd}$ & 23.65 & 7.38 & 7.38 & 7.66 & 4.80 & 34.30 & 5.76 & 3.13 & 17.80 & 9.32 & 10.41 & 34.68 \\
\hline $\mathrm{Sm}$ & 4.10 & 1.76 & 1.76 & 1.81 & 1.37 & 8.04 & 1.32 & 0.92 & 3.20 & 2.25 & 1.95 & 7.14 \\
\hline $\mathrm{Eu}$ & 1.13 & 0.70 & 0.70 & 0.48 & 0.42 & 1.98 & 0.49 & 0.30 & 0.90 & 0.68 & 0.62 & 1.70 \\
\hline $\mathrm{Gd}$ & 3.71 & 2.12 & 2.12 & 1.89 & 1.25 & 7.38 & 1.49 & 0.91 & 2.45 & 2.21 & 1.84 & 5.04 \\
\hline $\mathrm{Tb}$ & 0.54 & 0.35 & 0.35 & 0.30 & 0.22 & 1.14 & 0.24 & 0.17 & 0.43 & 0.34 & 0.28 & 0.82 \\
\hline Dy & 2.96 & 2.16 & 2.16 & 1.79 & 1.41 & 6.56 & 1.48 & 1.05 & 2.36 & 1.92 & 1.51 & 4.69 \\
\hline Ho & 0.57 & 0.41 & 0.41 & 0.34 & 0.27 & 1.24 & 0.30 & 0.24 & 0.43 & 0.36 & 0.30 & 0.78 \\
\hline $\mathrm{Er}$ & 1.60 & 1.25 & 1.25 & 0.98 & 0.78 & 3.43 & 0.85 & 0.66 & 1.15 & 1.00 & 0.84 & 2.19 \\
\hline $\mathrm{Tm}$ & 0.24 & 0.18 & 0.18 & 0.14 & 0.12 & 0.48 & 0.13 & 0.09 & 0.17 & 0.15 & 0.13 & 0.30 \\
\hline $\mathrm{Yb}$ & 1.49 & 1.14 & 1.14 & 0.90 & 0.72 & 2.93 & 0.81 & 0.60 & 1.10 & 0.92 & 0.81 & 1.97 \\
\hline $\mathrm{Lu}$ & 0.23 & 0.17 & 0.17 & 0.14 & 0.11 & 0.45 & 0.12 & 0.09 & 0.17 & 0.14 & 0.12 & 0.29 \\
\hline $\mathrm{Y}$ & 16.54 & 11.77 & 11.77 & 9.58 & 8.20 & 37.10 & 7.90 & 5.76 & 13.67 & 9.62 & 8.08 & 23.15 \\
\hline REE & 121.7 & 36.34 & 36.35 & 35.53 & 23.11 & 155.3 & 27.72 & 14.90 & 72.79 & 40.65 & 52.20 & 154.9 \\
\hline LREE & 110.3 & 28.57 & 28.57 & 29.05 & 18.23 & 131.7 & 22.29 & 11.09 & 64.53 & 33.70 & 46.50 & 138.8 \\
\hline HREE & 11.34 & 7.78 & 7.78 & 6.48 & 4.88 & 23.61 & 5.43 & 3.81 & 8.26 & 6.95 & 5.70 & 16.08 \\
\hline LREE/HREE & 9.73 & 3.67 & 3.67 & 4.48 & 3.74 & 5.58 & 4.10 & 2.91 & 7.81 & 4.85 & 8.16 & 8.63 \\
\hline$(\mathrm{La} / \mathrm{Lu}) \mathrm{n}$ & 10.91 & 3.14 & 3.10 & 3.64 & 3.17 & 5.71 & 3.28 & 2.15 & 6.63 & 5.40 & 9.97 & 7.91 \\
\hline$\delta \mathrm{Eu}$ & 0.87 & 1.11 & 1.11 & 0.79 & 0.96 & 0.77 & 1.06 & 0.99 & 0.95 & 0.94 & 0.95 & 0.82 \\
\hline
\end{tabular}

Samples of HQL02-3, HQL02-5-7, H7-3-5 and P4-8 are average values after [14]; Samples of HQI-11-20, HQV-5-21 and HQV-7-20 are average values after [13]. Samples of HQLF-11 are average values after [14]. 


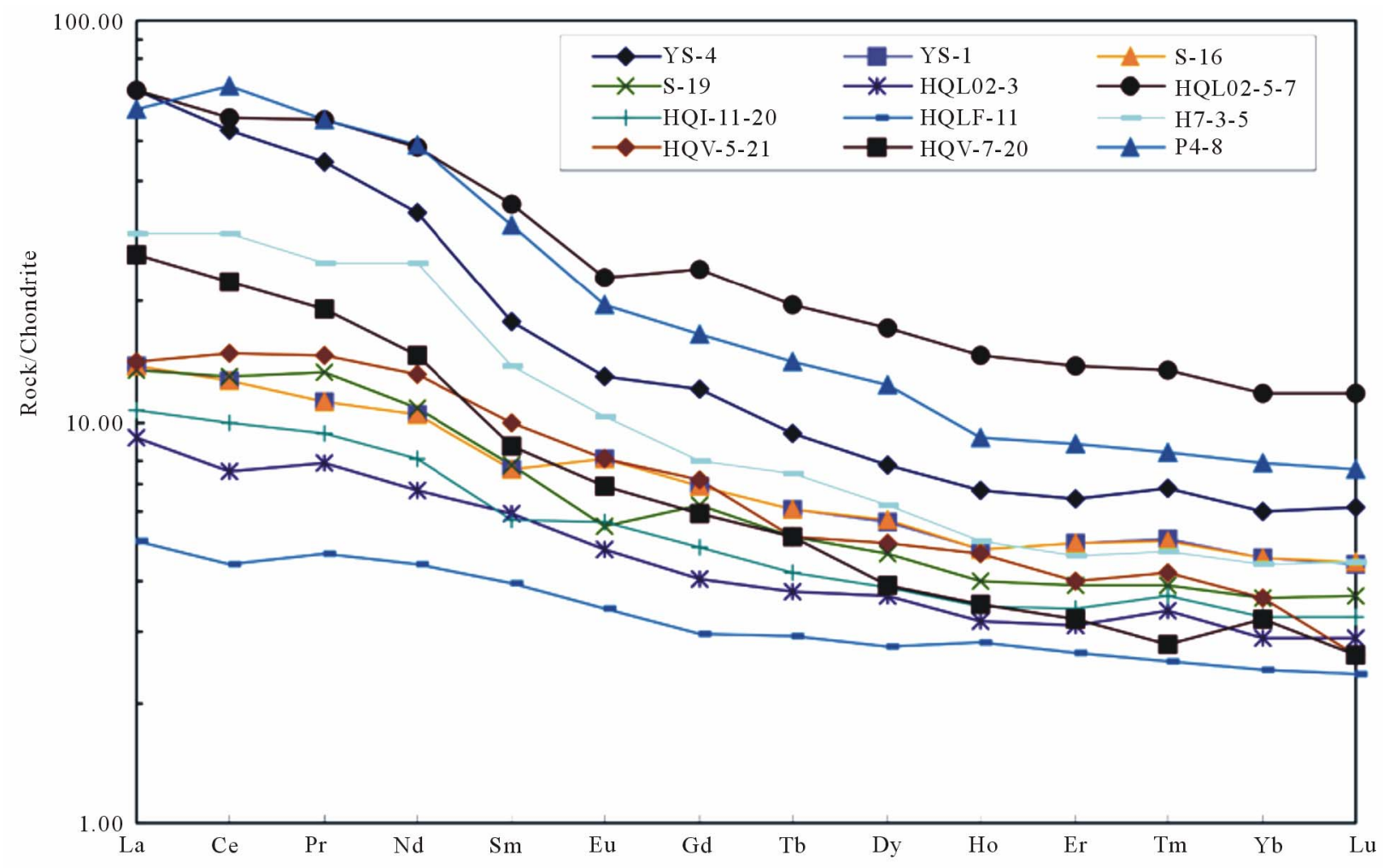

Figure 3. Chondrite-normalized REE patterns for mafic-ultramafic intrusions.

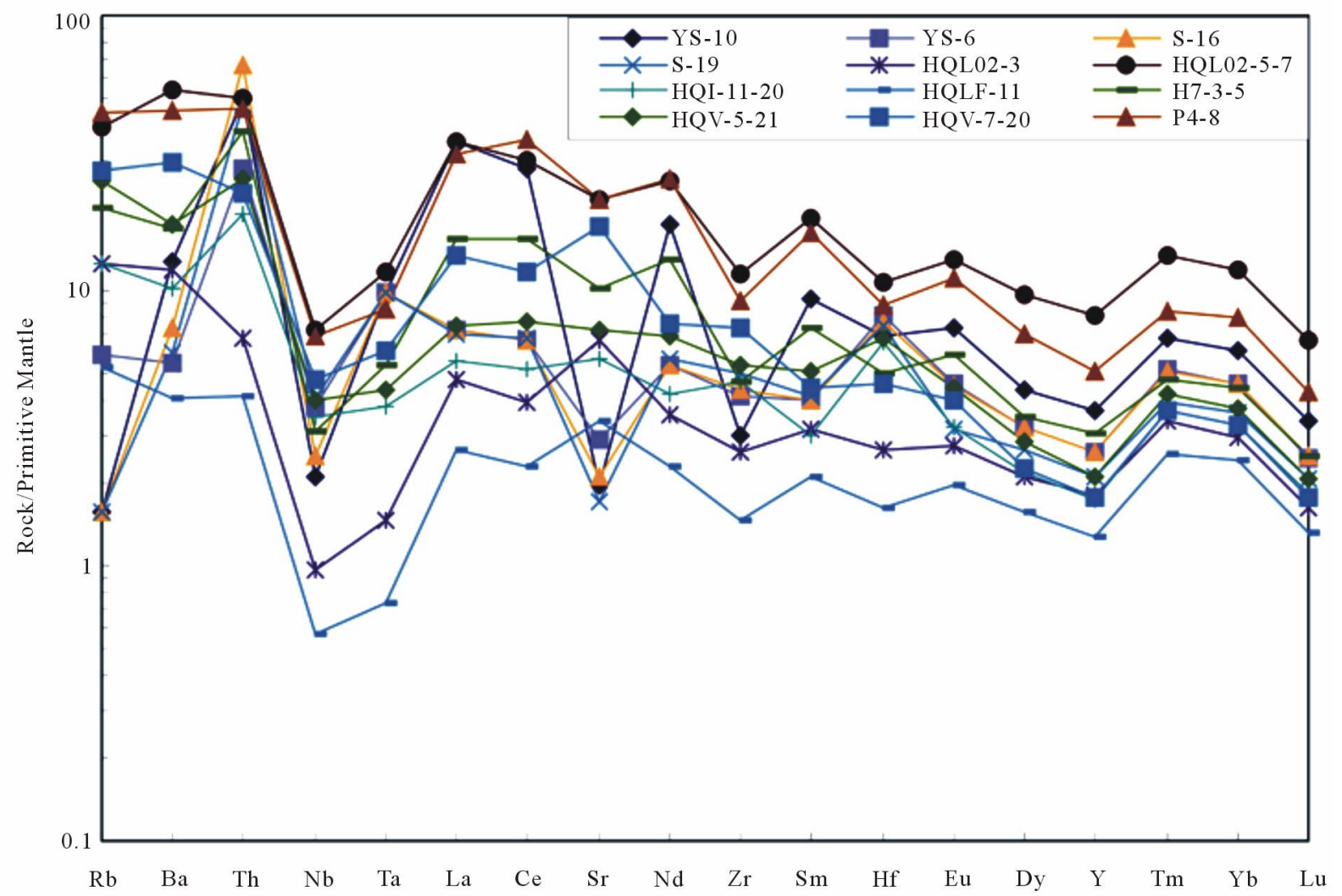

Figure 4. Primitive-mantle normalized spidergrams for mafic-ultramafic intrusions. 

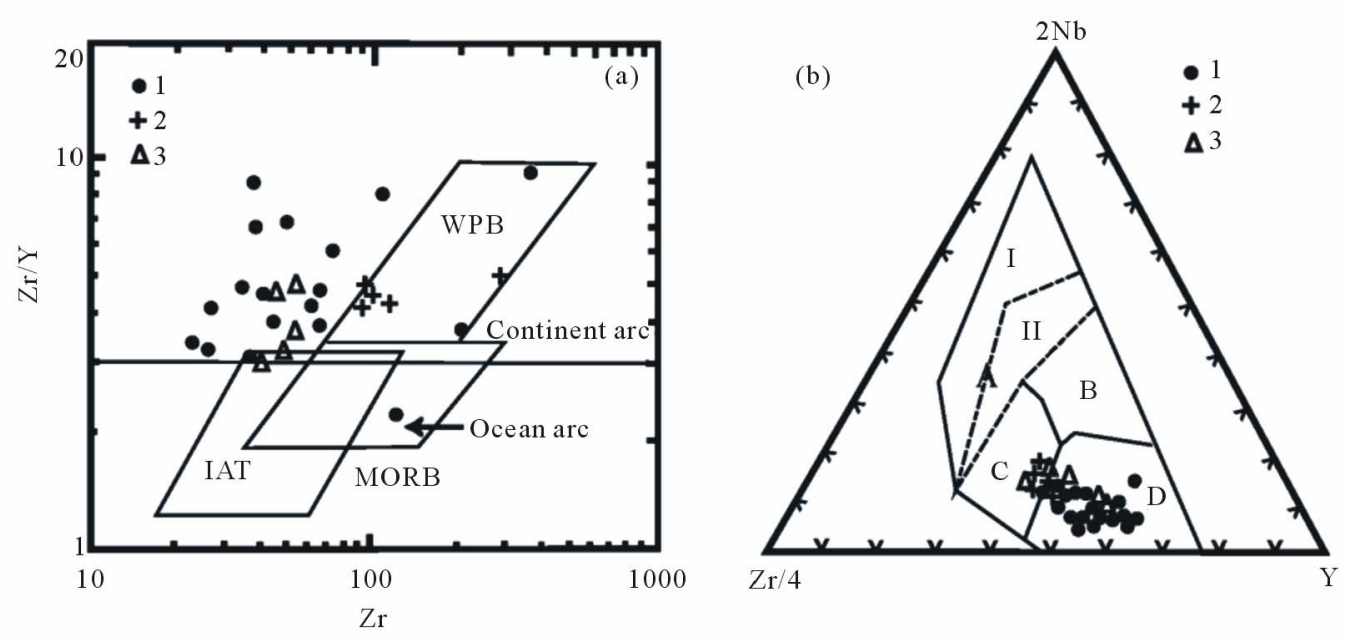

Figure 5. Zr/Y-Zr (a) and 2Nb-Zr/4-Y (b) discrimination diagram of the mafic-ultramafic rocks in North Jilin Province, China (after [24]). (a) WPB. basalt in continental intra plate; MORB. basalt in middle ocean ridge; IAT. basalt in arc; (b) A. I and II continental intra plate; II and C. tholeiite in continental intra plate; B. P-MORB (P-type rich MORB); D. N-MORB(N type deficit MORB); C. and D. basalt in volcanic arc; 1. samples of Hongqiling complexes; 2. samples of Sandaogang complexes; 3 . samples of Piaohechuan complexes.

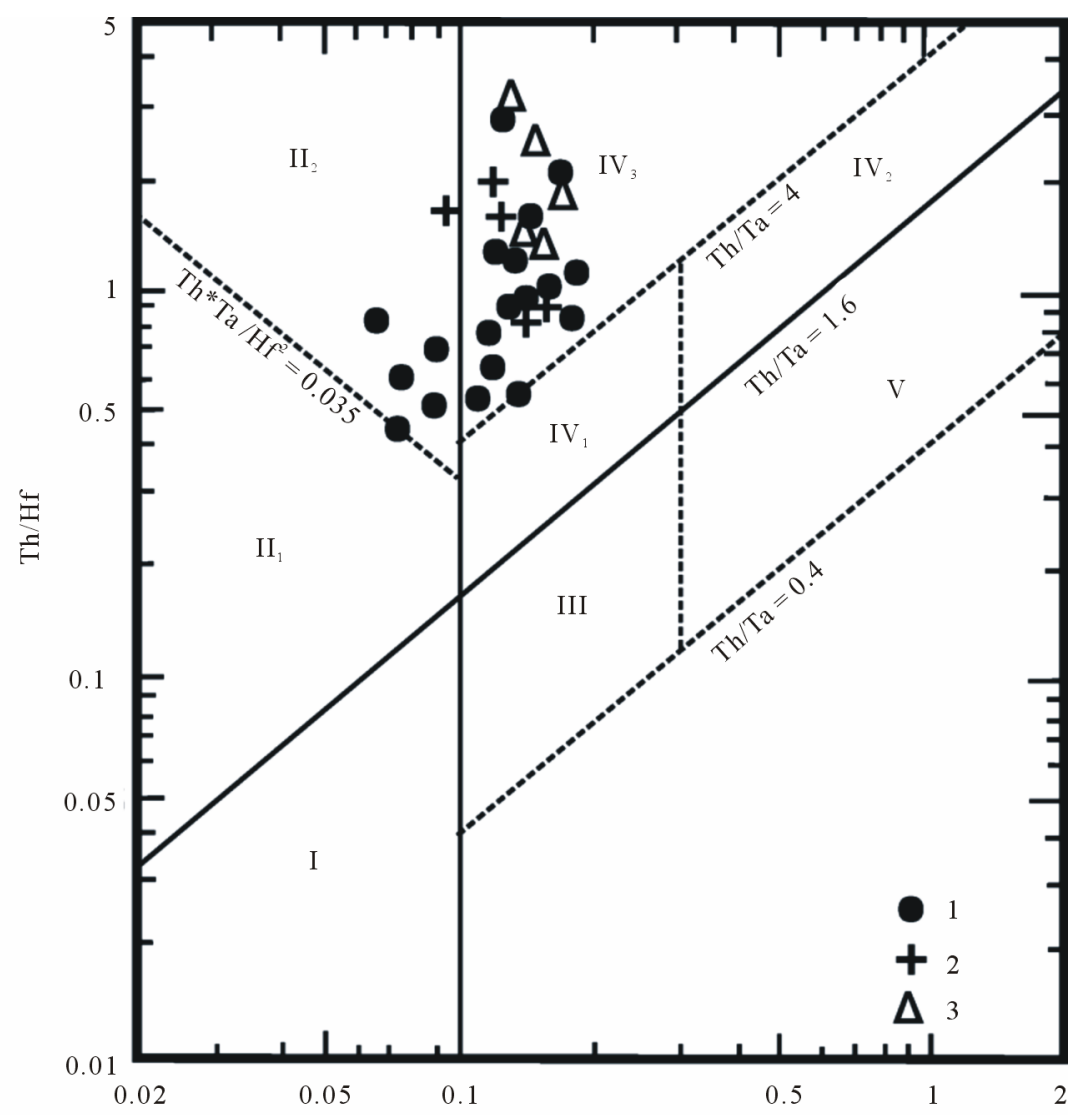

Figure 6. Th/Hf and Ta/Hf discrimination diagram of the mafic-ultramafic rocks in North Jilin Province, China (after [25]). I. The margin of divergent oceanic plate. $\mathrm{II}$. The margin of convergent plate $\left(\mathrm{II}_{1}\right.$ : oceanic island arc; $\mathrm{II}_{2}$ : island arc and volcanic arc of continental margin). III. The oceanic intra plate( the oceanic island and sea mount, T-MORB, E-MORB). IV. Within continental plate (IV1: tholeiite in continental rift and margin rift; $I_{2}$ : alkaline basalt in continental rift; $I V_{3}$ : continental extensional zone(or initial rift). V. Mantle plume; 1. samples of Hongqiling complexes; 2. samples of Sandaogang complexes; 3. samples of Piaohechuan complexes. 


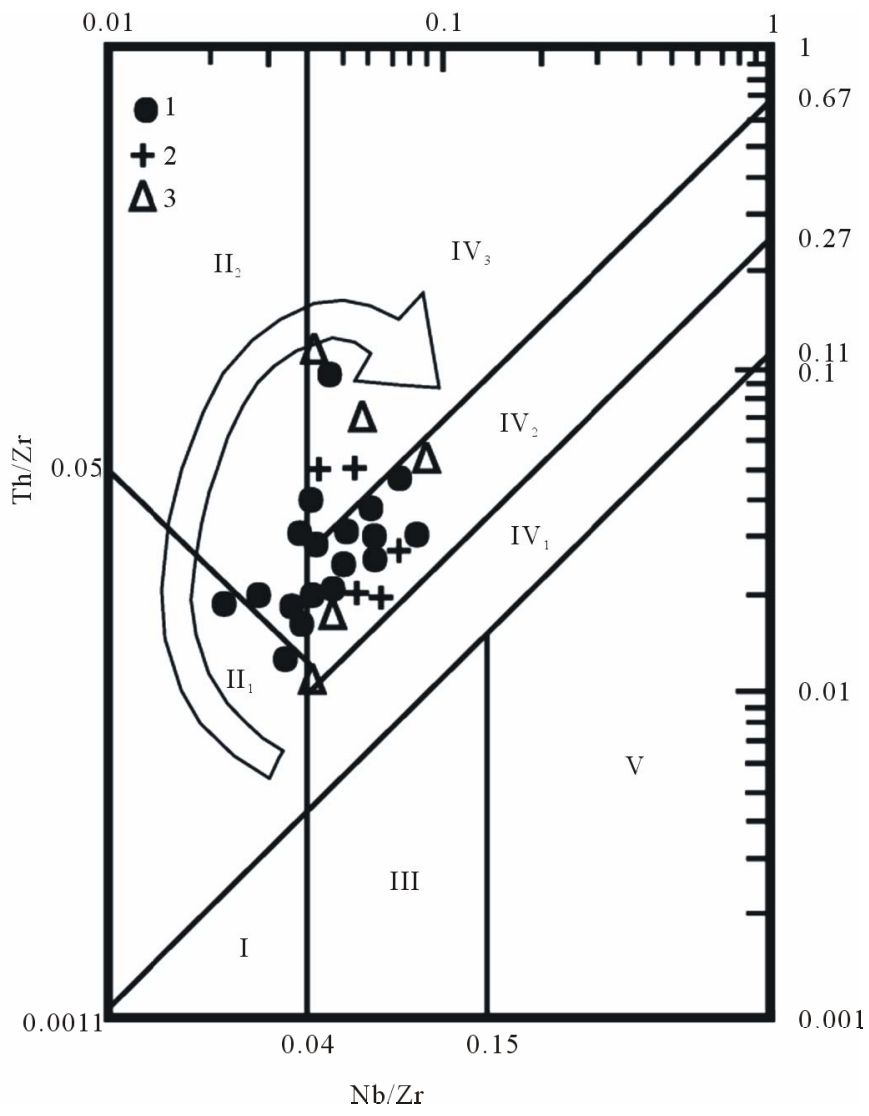

Figure 7. Th/Zr and Ta/Zr discrimination diagram of the mafic-ultramafic rocks in North Jilin Province, China (after [26]). I. The margin of divergent oceanic plate. $\mathrm{II}$. The margin of convergent plate $\left(\mathrm{II}_{1}\right.$ : oceanic island arc; $\mathrm{II}_{2}$ : island arc and volcanic arc of continental margin). III. The oceanic intra plate (the oceanic island and sea mount, T-MORB, E-MORB). IV. Within continental plate $\left(\mathrm{IV}_{1}\right.$ : continental rift; $\mathrm{IV}_{2}$ : continental extensional zone; $\mathrm{IV}_{3}$ : collision zone of two continental plates). $\mathrm{V}$. Mantle plume; 1. samples of Hongqiling complexes; 2. samples of Sandaogang complexes; 3. samples of Piaohechuan complexes.

0.70408 and ${ }^{143} \mathrm{Nd} /{ }^{144} \mathrm{Nd}$ rations is between 0.51254 to $0.51256, \varepsilon_{\mathrm{Nd}}(\mathrm{t})$ values is between 0.2 to $4.3[12,14]$, all data put in the depleted mantle source in $\left({ }^{87} \mathrm{Sr} /{ }^{86} \mathrm{Sr}\right) \mathrm{i}-\varepsilon_{\mathrm{Nd}}(\mathrm{t})$ diagram(Figure 8).

The feature of the low $\mathrm{SiO}_{2}, \mathrm{~K}_{2} \mathrm{O}$ and high $\mathrm{MgO}$, as well as low initial ${ }^{87} \mathrm{Sr} /{ }^{86} \mathrm{Sr}$ rations and positive $\varepsilon_{\mathrm{Nd}}(\mathrm{t})$, which implies the intrusions come form partial melting of depleted mantle. Although asthenospheric mantle and lithospheric mantle both can be formed depleted mantle, but the pattern of enriched in LREE and depleted in $\mathrm{Nb}$, Ta (Figures 3 and 4) were very difference form the MORB or OIB that divided form the depleted asthenospheric mantle, therefore all those suggest that the intrusions come form the depleted lithospheric mantle. The depleted lithospheric mantle possible is juvenile supported by the zircon $\mathrm{Hf}$ isotope in the intrusion of Hongqiling. The rang of ${ }^{176} \mathrm{Hf} /{ }^{177} \mathrm{Hf}$ ratios is from 0.282907 to 0.283042 , average value is $0.282980 \pm 21$ $(2 \sigma, \mathrm{n}=13)$ and $\varepsilon_{\mathrm{Hf}}(220 \mathrm{Ma})$ is 12.3 , the ranger of the two-stage $\mathrm{Hf}$ model age $\left(\mathrm{t}_{\mathrm{DM} 2}\right)$ is from 333 to $639 \mathrm{Ma}$ and the average value is $465 \mathrm{Ma}$ (Table 3 ), which indicate that the lithospheric mantle were transformed during $\mathrm{Pa}$ leozoic.

\section{Discussion and Conclusions}

\subsection{Discussion of the Tectonic Setting}

According to the regional geological survey [3], there are four obvious regional angular unconformities in north Jilin Province. One is between Early Paleozoric Hulan Group with amphibolite facies metamorphism and Permian strata with no metamorphism, which probable reflect the Caledonian orogeny in the area. Second is between Late Permian strata and Early Triassic strata, as there are molasse formation in the bottom of Early Triassic Lujiatun Formation and contains fossil of Neocalamites sp. Podozamites sp. Corina lutkevichi, Cetata, C. subguadrata [3], so the Hercynian orogeny also may be exist. The third is between Early Triassic Lujiatun Formation and Late Triassic strata, which suggest there was Indosinian orogenic movement. The fourth is between Late Triassic strata and Early Jurassic-Cretaceous strata, 


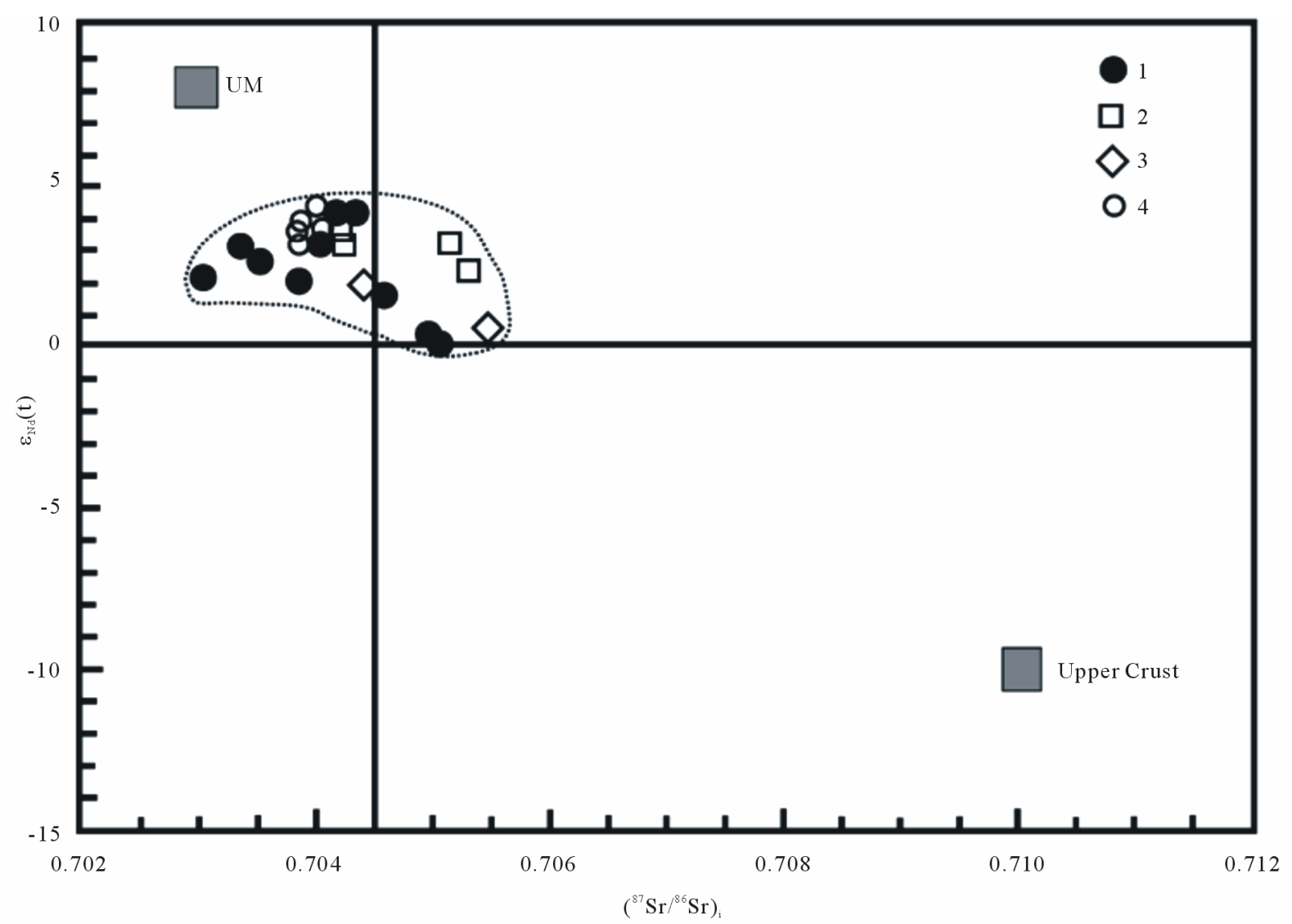

Figure 8. $\varepsilon_{\mathrm{Nd}}(\mathrm{t})$ vs. $\left({ }^{87} \mathrm{Sr} /{ }^{86} \mathrm{Sr}\right)_{\mathrm{i}}$ diagram showing plot range of the depleted mantle (1. samples of Hongqiling complexes, after [12]; 2. samples of Piaohechuan complexes, after [12]; 3. samples of Chajianling complexes, after [12]; 4. samples of Hongqiling complexes, after [14]).

Table 3. Zircon hafnium isotopic composition of Hongqiling ultramafic rock (Sample HQL01).

\begin{tabular}{cccccccccccc}
\hline Point & ${ }^{176} \mathrm{Lu} /{ }^{177} \mathrm{Hf}$ & $2 \sigma$ & ${ }^{176} \mathrm{Hf} /{ }^{177} \mathrm{Hf}$ & $2 \sigma$ & $\mathrm{Age}(\mathrm{Ma})$ & $\left({ }^{176} \mathrm{Hf} /{ }^{177} \mathrm{Hf}\right)_{\mathrm{t}}$ & ${ }^{\mathrm{Hff}}(0)$ & $\varepsilon_{\mathrm{Hf}}(\mathrm{t})$ & $t_{\mathrm{DM} 1}(\mathrm{Ma})$ & $t_{\mathrm{DM} 2}(\mathrm{Ma})$ & $f_{\mathrm{Lu} / \mathrm{Hf}}$ \\
\hline 1 & 0.001024 & 0.000028 & 0.282911 & 0.000029 & 220 & 0.282907 & 4.9 & 9.6 & 484 & 639 & -0.97 \\
2 & 0.001244 & 0.000048 & 0.282995 & 0.000048 & 220 & 0.282989 & 7.9 & 12.5 & 367 & 453 & -0.96 \\
3 & 0.000498 & 0.000012 & 0.282957 & 0.000021 & 220 & 0.282955 & 6.5 & 11.3 & 413 & 531 & -0.99 \\
4 & 0.000854 & 0.000012 & 0.283021 & 0.000023 & 220 & 0.283018 & 8.8 & 13.5 & 326 & 389 & -0.97 \\
5 & 0.001460 & 0.000012 & 0.282985 & 0.000023 & 220 & 0.282979 & 7.5 & 12.1 & 384 & 477 & -0.96 \\
6 & 0.001329 & 0.000007 & 0.283046 & 0.000032 & 220 & 0.283040 & 9.7 & 14.3 & 294 & 337 & -0.96 \\
7 & 0.001562 & 0.000035 & 0.282959 & 0.000024 & 220 & 0.282953 & 6.6 & 11.2 & 422 & 536 & -0.95 \\
8 & 0.001373 & 0.000023 & 0.283032 & 0.000029 & 220 & 0.283027 & 9.2 & 13.8 & 314 & 369 & -0.96 \\
9 & 0.000588 & 0.000003 & 0.282971 & 0.000022 & 220 & 0.282969 & 7.0 & 11.8 & 394 & 500 & -0.98 \\
10 & 0.001170 & 0.000002 & 0.282966 & 0.000025 & 220 & 0.282961 & 6.9 & 11.5 & 407 & 516 & -0.96 \\
11 & 0.000661 & 0.000004 & 0.282970 & 0.000019 & 220 & 0.282967 & 7.0 & 11.7 & 397 & 504 & -0.98 \\
12 & 0.000874 & 0.000004 & 0.283046 & 0.000028 & 220 & 0.283042 & 9.7 & 14.4 & 291 & 333 & -0.97 \\
13 & 0.001006 & 0.000007 & 0.282991 & 0.000020 & 220 & 0.282987 & 7.7 & 12.4 & 370 & 459 & -0.97 \\
\hline
\end{tabular}


which suggest there was Yanshanian orogenic movement in the area. However the Indosinian orogenic movement can be divided into tow stages by the difference of tectonic styles. As the loss of Middle Triassic strata and the fold of the Late Permian strata together with Early Triassic Lujiatun Formation, which discovered the Early Indosinian orogenic movement and it was more obviously than Hercynian orogeny, but after this orogenic movement, some Late Triassic continental basins were appeared and sediments and continental volcanic rocks formed, such as the coarse sediments in Late Triassic Dajianggang Formation [3], the 220 - 200 Ma bimodal volcanic rock in Tuopangou Formation and Tianqiaoling Formation [28], moreover, appearance of A-type granitic rocks emplaced at about 214 - $199 \mathrm{Ma}$ [20] and lkaline rocks intruded at about $223 \pm 1 \mathrm{Ma}$ [29], as well as the mafic-ultramafic complexes, which expressed there was also tectonic movement in Late Triassic period, no more than it was transformed form extrusion to extension.

Orogenic I-type granites in Late Permian and Early Triassic period [30-33] and 240 Ma sanukitie [34] were widespread in north Jilin province, which indicate the lithosphere thickening and crustal accretion. But the bimodal igneous rock assemblage formed in Late Indosinian period, which indicate the lithospheric thinning and crustal extension. The lithospheric thinning and crustal extension may be caused by the upwelling of asthenosphere and underplating in post-orogenic period [35], which may be produced the new depleted lithospheric mantle, the partial milting of the depleted lithospheric mantle formed the primitive magma of the mafic-ultramafic complexes.

\subsection{Conclusions}

1) There are similar zircon U-Pb age of the maficultramafic complexes in north Jilin Province, range formed $217 \mathrm{Ma}$ to $232 \mathrm{Ma}$, which means that the complexes were formed in Late Indosinian period and belong to one tectonic magmatic event.

2) The mafic-ultramafic rocks can be divided in some rock assemblages, which is different with the ophiolite type and Yidun type in orogenic belt. This suggests that the rock assemblage may be particular type in post-orogenic belt. The mafic-ultramafic complexes and A-type granites formed bimodal igneous rock assemblage, which indicated extended setting.

3) The mafic-ultramafic rocks belong to high-Mg and low $\mathrm{K}$ tholeiitic series related with inter-continental postorogenic tectonic setting. The trace element compositions show that the intrusions formed mainly in continental extended belt and have the characteristics of revolution from oceanic island arc, volcanic arc of continental margin to continental extended belt. The complexes were the products during the late period developed from Early Indosinian extrusion orogenic processes to Late Indosinian extended post-orogenic processes in the Xing'anMongolian Orogenic Belt. The Sr-Nd isotope and zircon Hf isotope suggested that the initial magma of the complexes come from the parting melting of juvenile depleted lithospheric mantle.

4) There are may be two tectonic setting for mafic- ultramafic complexes formed in orogenic belt, one is the tectonic setting of extrusion and crust accretion in early stage, in which the complexes can be defined as orogenic type, it can be divided into subtypes of ophiolite type and Yidun type, such as the mafic-ultramafic complexes in Tarlang area [36] and Kalatongke [37,38] in North Xinjiang, Northwest China, other is the tectonic setting of extension and lithospheric thinning in late stage, in which the complexes can be defined as post-orogenic type, such as complexes in north Jilin Province, Northeast China.

\section{Acknowledgements}

We are grateful to the previous studies for the data of the mafic-ultramafic complexes in north Jilin Province. This study was financially supported by Natural Science Foundation of P. R. China (Grants No. 40973019). This paper is a contribution to 12 th International Ni-Cu-(PGE) Symposium, Guiyang, Guizhou China.

\section{REFERENCES}

[1] A. J. Naldrett and L. J. Cabri, "Ultramafic and Related Mafic Rocks: Their Classification and Genesis with Special Reference to the Concentration and Platinum-Group Elements," Economic Geology, Vol. 71, No. 7, 1976, pp. 1131-1158. doi:10.2113/gsecongeo.71.7.1131

[2] A. J. Naldrett, "World-Class Ni-Cu-PGE Deposits: Key Factors in Their Genesis," Mineralium Deposita, Vol. 34, No. 3, 1999, pp. 227-240. doi:10.1007/s001260050200

[3] Jilin Bureau of Geology and Mineral Resources, "Regional Geology of Jilin Province," Geology Press, Beijing, 1988.

[4] D. B. Fu and E. Z. Chen, "Metallogenetic Regularities of $\mathrm{Cu}-\mathrm{Ni}$ Sulfide Deposits in Jilin Province," Jilin Geology, Vol. 7, No. 2, 1988, pp. 124-144.

[5] Z. L. Tang and W. Y. Li, "Studies of Metallogenic Regularity of Nickel Sulfide Deposits in China and Their Prospects," Mineral Deposit, Vol. 10, No. 3, 1991, pp. 193203.

[6] A. H. Xi, H. M. Ren, B. L. Li, Y. X. Wang and S. B. Shi, "Petrology and Geochemistry of the Ore-Bearing Intrusions in Hongqiling Cu-Ni Sulfide Deposit, Jilin Province," Journal of Jilin University (Earth Science Edition), Vol. 32, No. 2, 2002, pp. 140-145.

[7] G. C. Zhao, S. A.Wilde, P. A.Cawood, M. Sun and L. Z. $\mathrm{Lu}$, "Archean Blocks and Their Boundaries in the North China Craton: Lithological, Geochemical, Structural and 
P-T Path Constraints," Precambrian Research, Vol. 107, No. 1-2, 2001, pp. 45-73. doi:10.1016/S0301-9268(00)00154-6

[8] Q. Zhang, K. W. Zhang and D. Z. Li, "The Classification of Basic and Ultrabasic Rocks from Hengduanshan Region," Acta Petrologica Sinica, Vol. 3, No. 3, 1987, pp. 135- 148.

[9] C. A. Liu and J. C. Shan, "The Tectonic Features of Mongolia-Okhotsk Plate," Journal of Changchun College of Geology, Vol. 9, No. 2, 1979, pp. 1-12.

[10] D. C. Jia, "A Preliminary Study on the Tectonic Framework of Paleoplate in the Central Part of Jilin Province," Jilin Geology, Vol. 7, No. 3, 1988, pp. 58-64.

[11] Z. C. Chen, "The Geological Features and Metallogenic Model of Cu-Ni Sulfide Deposits in Jilin Province," Geology and Prospecting, Vol. 27, No. 10, 1991, pp. 1-10.

[12] F. Y. Wu, A. Wilde Simon, G. L. Zhang and D. Y. Sun, "Geochronology and Petrogenesis of the Post-Orogenic $\mathrm{Cu}-\mathrm{Ni}$ Sulfide-Bearing Mafic-Ultramafic Complexes in Jilin Province, NE China," Journal of Asian Earth Sciences, Vol. 23, No. 5, 2004, pp. 781-797. doi:10.1016/S1367-9120(03)00114-7

[13] A. H. Xi, L. X. Gu, X. J. Li and Y. C. Zheng, "The Magmatic Sulphide $\mathrm{Cu}-\mathrm{Ni}$ Deposits and Their Earth Dynamics Setting in North Orogenic Belt of China: A Case Study of Hongqiling Deposits," Acta Geologica Sinica, Vol. 80, No. 11, 2006, pp. 1721-1729.

[14] G. Y. Feng, S. Liu, C. X. Feng, D. C. Jia, H. Zhong, X. F. $\mathrm{Yu}, \mathrm{Y}$. Q. Qi and T. Wang, "Zircon U-Pb Age, Sr-Nd-Hf Isotope Geochemistry and the Petrogenesis of Ultramafic Pluton in Hongqiling, Jilin Province," Acta Petrologica Sinica, Vol. 27, No. 6, 2011, pp. 1594-1606.

[15] F. Y. Wu, B. M. Jahn, S. Wilde and D. Y. Sun, "Phanerozoic Continental Crustal Growth: Sr-Nd Isotopic Evidence from the Granites in Northeastern China," Tectonophysics, Vol. 328, No. 1-2, 2000, pp. 89-113. doi:10.1016/S0040-1951(00)00179-7

[16] F. Guo, W. M. Fan, X. F. Gao, C. W. Li, L. C. Miao, L. Zhao and $\mathrm{H}$. X. Li, "Sr-Nd-Pb Isotope Mapping of Mesozoic Igneous Rocks in NE China Constraints on Tectonic Framework and Phanerozoic Crustal Growth," Lithos, Vol. 120, No. 3-4, 2010, pp. 563-578. doi:10.1016/j.lithos.2010.09.020

[17] F. Y. Wu, D. Y. Sun, W. C. Ge, Y. B. Zhang, M. L. Grant, S. A. Wilde and B. M. Jahn, "Geochronology of the Phanerozoic Granitoids in Northeastern China," Journal of Asian Science, Vol. 41, No. 4, 2011, pp. 1-30.

[18] A. H. Xi, Y. F. Cai, Y. H. Ge, G. S. Sun and B. L. Li, "LA-ICP-MS Zircon U-Pb Age of Longwang Gabbro of Shanmen Silver Deposit in Siping and Its Geological Significance," Mineral Deposits, Vol. 27, No. 1, 2008, pp. 57-63.

[19] Z. G. Wang, A. H. Xi, Y. H. Ge, P. H. Gong and B. Wang, "Chronology Significance of the Intrusion Group in Sandaogang Cu-Ni Sulfide Deposit, Panshi, Jilin Province," Journal of Jilin University (Earth Science Edition), Vol. 41, No. S1, 2011, pp. 126-132.

[20] F. Y. Wu, D. Y. Sun, H. M. Li, B. M. Jahn and S. A.
Wilde, "A-Type Granites in Northeastern China: Age and Geochemical Constraints on Their Petrogenesis," Chemical Geology, Vol. 187, No. 1-2, 2002, pp. 143-173. doi:10.1016/S0009-2541(02)00018-9

[21] S. Liu, R. Z. Hu, S. Gao, C. X. Feng, L. Qi, H. Zhong, T. F. Xiao, Y. Q. Qi, T. Wang and I. M. Coulson, "Zircon $\mathrm{U}-\mathrm{Pb}$ Geochronology and Major, Trace Elemental and $\mathrm{Sr}-\mathrm{Nd}-\mathrm{Pb}$ Isotopic Geochemistry of Mafic Dykes in Western Shandong Province, East China: Constrains on Petrogenesis and Geodynamic Significance," Chemical Geology, Vol. 255, No. 3-4, 2008, pp. 329-345. doi:10.1016/j.chemgeo.2008.07.006

[22] W. P. Leeman and J. G. Fitton, "Magmatism Associated with Lithospheric Extension: Introduction," Journal of Geophysical Research, Vol. 94, No. B6, 1989, pp. 76827684. doi:10.1029/JB094iB06p07682

[23] W. F. McDonough, "Constraints on the Composition of the Continental Lithospheric Mantle," Earth and Planetary Science Letters, Vol. 101, No. 1, 1990, pp. 1-18. doi:10.1016/0012-821X(90)90119-I

[24] J. A. Pearce and J. R. Cann, "Tectonic Setting of Basic Volcanic Rocks Investigated Using Trace Element Analyses," Earth and Planetary Science Letters, Vol. 19, No. 2, 1973, pp. 290-300. doi:10.1016/0012-821X(73)90129-5

[25] Y. L. Wang, C. J. Zhang and S. Z. Xiu, "Th/Hf-Ta/Hf Identification of Tectonic Setting of Basalts," Acta Petrologica Sinica, Vol. 17, No. 3, 2001, pp. 413-421.

[26] S. Q. Sun, C. J. Zhang and R. Q. Huang, "The Tectonic Settings Discrimination of the Basalts in the Convergent Margin of Plate by $\mathrm{Th}, \mathrm{Nb}$ and $\mathrm{Zr}$," Advances in Earth Science, Vol. 21, No. 6, 2006, pp. 593-598.

[27] A. W. Hofman, "Chemical Differentiation of the Earth: The Relationship between Mantle, Continental Crust, and Oceanic Crust," Earth and Planetary Science Letters, Vol. 90, No. 3, 1988, pp. 297-314. doi:10.1016/0012-821X(88)90132-X

[28] F. P. Pei, W. L. Xu and K. Jin, "Petro-Geochemical Characteristics and Tectonic Significance of Late Triassic Volcanic Rocks in Yanbian Area, Northeastern China," Global Geology, Vol. 23, No. 1, 2004, pp. 6-13.

[29] Y. B. Zhang, F. Y. Wu, S. A. Wilde, M. G. Zhai and X. P. $\mathrm{Lu}$, "Zircon U-Pb Ages and Tectonic Implications of 'Early Paleozoic' Granitoids at Yanbian, Jilin Province, Northeast China," The Island Arc, Vol. 13, No. 4, 2004, pp. 484-505. doi:10.1111/j.1440-1738.2004.00442.x

[30] C. B. Zhao, K. Jin, C. D. Qi and Y. J. Peng, "Characteristics of the Early Indo-Chinese I-A Type Granite Series in the Hunchun Area, Jilin Province and Its Geotectonic Significance," Jilin Geology, Vol. 20, No. 1, 2001, pp. 1-11.

[31] C. D. Qi, C. H. Ji, J. Han, A. C. Guo, X. Di and Y. X. Sun, "The Genetic Mechanism of the Late Permian-Early Triassic Granite from Jilin to Hunchun," Jilin Geology, Vol. 24, No. 2, 2005, pp. 10-16.

[32] F. Y. Wu, B. M. Jahn, S. A. Wilde, C. H. Lo, T. F. Yui, Q. Lin, W. C. Ge and D. Y. Sun, "Highly Fractionated I-Type Granites in NE China (I): Geochronology and Petrogenesis," Lithos, Vol. 66, No. 3-4, 2003, pp. 241273. doi:10.1016/S0024-4937(02)00222-0 
[33] F. Y. Wu, B. M. Jahn, S. A. Wilde, C. H. Lo, T. F. Yui, Q. Lin, W. C. Ge and D. Y. Sun, "Highly Fractionated I-Type Granites in NE China (II): Isotopic Geochemistry and Implications for Crustal Growth in the Phanerozoic," Lithos, Vol. 67, No. 3-4, 2003, pp. 191-204. doi:10.1016/S0024-4937(03)00015-X

[34] C. L. Fu, D. Y. Sun, X. Z. Zhang, H. Y. Wei and J. Gou, "Discovery and Geological Significance of the Triassic High-Mg Diorites in Hunchun Area, Jilin Province," Acta Petrologica Sinica, Vol. 26, No. 4, 2010, pp. 1089-1102.

[35] J. A. Shao, L. Q. Zhang and B. L. Nie, "Magmatism in the Mesozoic Extending Orogenic Process of Da Hinggan Mts," Earth Sciences Frontiers, Vol. 6, No. 4, 1999, pp. 339-346.

[36] K. D. Cai, C. Yuan, M. Sun, W. J. Xiao, H. L. Chen, Y. J. Zhao and J. L. Li, "Geochemical Characteristics and ${ }^{40} \mathrm{Ar}-$
${ }^{39} \mathrm{Ar}$ Age of the Amphibolites and Gabbros in Tarlang Area: Implications for Tectonic Evolution of the Chinese Altai," Acta Petrologica Sinica, Vol. 23, No. 5, 2007, pp. 877-888.

[37] Z. C. Zhang, J. W. Mao, F. M. Chai, S. Yan, B. L. Chen and F. Pirajno, "Geochemistry of the Permian Kalatongke Mafic Intrusions, North Xinjiang, Northwest China: Implications for the Genesis of Magmatic Ni-Cu Sulfide Deposits," Economic Geology, Vol. 104, No. 2, 2009, pp. 185-203. doi:10.2113/gsecongeo.104.2.185

[38] J. F. Gao, M. F. Zhou, P. C. Lightfoot, Y. W. Christina and L. Qi, "Origin of PGE-Poor and Cu-Rich Magmatic Sulfides from the Kalatongke Deposit, Xinjiang, Northwest China," Economic Geology, Vol. 107, No. 3, 2012, pp. 481-506. doi:10.2113/econgeo.107.3.481 